\title{
De Zuid-Afrikaan se kommentaar op vraagstukke rakende bruin en swart mense in die Kaapkolonie tydens die redakteurskap van J.H. Hofmeyr (1871-1883)
}

\author{
Pieter de Klerk*
}

\section{Opsomming}

In die laat negentiende eeu was Jan Hendrik Hofmeyr (1845-1909) die leidende figuur in die Afrikanerbond, 'n prominente politieke party in die Kaapkolonie wat die belange van die blanke Afrikaanssprekende inwoners bevorder het. Hy was van 1871 tot 1883 ook redakteur van die Nederlandstalige koerant De Zuid-Afrikaan en sy beskouinge oor vraagstukke wat die bruin en swart inwoners van die kolonie raak kom in die redaksionele kolomme na vore. Die blad se standpunt rakende stemreg, militêre diens, arbeid, onderwys en die regeringsbeleid teenoor die swart mense in die oostelike grensgebied van die kolonie word in hierdie artikel bespreek. Om die probleem van arbeidstekorte op te los het Hofmeyr die invoer van werkers uit Indië, China en gebiede aangrensend aan die Kaapkolonie bepleit. Hy het hom aangesluit by die sogenaamde Kaapse liberale tradisie wat betref stemreg en die opname van die inheemse bevolking in die gedeeltelik verwesterste samelewing van die kolonie. In die jare van sy redakteurskap was hy ten gunste daarvan dat 'n groot aantal Europese immigrante asook bruin mense uit die Wes-Kaap in die oostelike dele van die kolonie gevestig word ten einde die proses van verwestersing van die swart inwoners te bespoedig.

Sleutelwoorde: J.H. Hofmeyr; De Zuid-Afrikaan; Kaapkolonie; bruin mense; stemreg; arbeidsvraagstukke; inboorlingbeleid.

\section{Abstract}

In the late nineteenth century J.H. Hofmeyr (1845-1909) was the leading figure in the Afrikaner Bond, a prominent political party in the Cape Colony that promoted the interests of the white Afrikaans-speaking population. During the period 1871 to 1883 he was also editor of the Dutch newspaper, De Zuid-Afrikaan, and his views on issues concerning the coloured and black residents of the colony are reflected in his editorial columns. The viewpoint of the newspaper on the franchise, military service, labour,

* $\quad$ Pieter de Klerk is emeritusprofessor in Geskiedenis en is verbonde aan die Vakgroep Geskiedenis van die Noordwes-Universiteit (Vaaldriehoekkampus). Sy e-pos adres is: deklerkpx@gmail.com

How to cite this article: P. de Klerk, De Zuid-Afrikaan se kommentaar op vraagstukke rakende bruin en swart mense in die Kaapkolonie tydens die redakteurskap van J.H. Hofmeyr (1871-1883), Historia 61, 2, November 2016, pp 101-120. http://dx.doi.org/10.17159/2309-8392/2016/v61n2a5 Copyright: (CThe Author(s). Published under a Creative Commons Attribution Licence. 
education and government policy regarding the black inhabitants in the eastern border area of the colony are discussed in this article. As a solution to the problem of the labour shortage, Hofmeyr supported the idea of importing labourers from India, China and areas bordering the Cape Colony. He followed the so-called Cape liberal tradition on issues regarding the franchise and the integration of the indigenous population in the partly Westernised society of the colony. During the years of his editorship he favoured the settlement of large numbers of European immigrants as well as coloured people from the Western Cape in the eastern part of the colony with the aim of accelerating the Westernisation of the black population.

Keywords: J.H. Hofmeyr; De Zuid-Afrikaan; Cape Colony; coloured people; franchise; labour issues; native policy.

\section{Inleiding}

Jan Hendrik Hofmeyr (1845-1909), ook bekend as "Onze Jan", word deur baie geskiedskrywers gereken as 'n belangrike figuur in die Suid-Afrikaanse geskiedenis. Hy het die Afrikaners van die Kaapkolonie verenig in die Afrikanerbond wat gedurende die periode 1880 tot 1910 'n groot rol in die politieke ontwikkeling van die kolonie gespeel het. Hofmeyr was gedurende hierdie jare een van die vernaamste politieke leiers in die Kaapkolonie en het ook heelwat invloed buite die grense van die kolonie gehad. Oor Hofmeyr se politieke beskouinge is nog geen uitgebreide wetenskaplike studie gedoen nie. Reeds vier jaar na sy dood het daar 'n biografie van hom verskyn, geskryf deur sy familielid, J.H. Hofmeyr, toe maar negentien jaar oud en later self 'n prominente politikus. ${ }^{1}$ Die boek bied 'n uitgebreide kronologiese oorsig, maar Onze Jan se politieke opvattinge word daarin maar kortliks bespreek. T.R.H. Davenport se studie van die Afrikanerbond ${ }^{2}$ gaan ook nie diep op Hofmeyr se politieke denke in nie. Hierdie artikel is 'n poging om die leemte in enkele opsigte te vul deur sy beskouinge te bekyk ten opsigte van vraagstukke rakende die bruin en swart inwoners van die Kaapkolonie gedurende die tydperk dat hy redakteur was van De Zuid-Afrikaan, naamlik van September 1871 tot Desember 1883.

De Zuid-Afrikaan, 'n koerant wat eers weekliks en later (vanaf 1841) twee maal per week verskyn het, is in 1830 opgerig om as mondstuk van die Nederlandstalige inwoners van die Kaapkolonie te dien. ${ }^{3}$ Dit was veral in die eerste drie dekades na sy

1. J.H. Hofmeyr en F.W. Reitz, Het Leven van Jan Hendrik Hofmeyr [Onze Jan] (Van de Sandt de Villiers, Kaapstad, 1913). 'n Engelstalige weergawe het ook verskyn: J.H. Hofmeyr and F.W. Reitz, The Life of Jan Hendrik Hofmeyr [Onze Jan] (Van de Sandt de Villiers, Cape Town, 1913). Reitz, voormalige president van die Oranje Vrystaat, het hoofsaaklik net in adviserende hoedanigheid opgetree. Vergelyk A. Paton, Hofmeyr (Oxford University Press, Cape Town, 1971), p 19. Laasgenoemde boek handel oor die jonger J.H. Hofmeyr (1894-1948).

2. T.R.H. Davenport, The Afrikaner Bond, 1880-1911 (Oxford University Press, Cape Town, 1966).

3. De Zuid-Afrikaan, 9 April 1830. In die eerste redaksionele artikel verwys die blad na sy lesers as "kolonisten", maar noem hulle ook "Afrikanen", 'n term wat dan verder 
oprigting 'n invloedryke blad. Gedurende die laaste jare van J.J.H. Smuts se lang redakteurstermyn (1845-1871) het die leserstal verminder. Dit was die gevolg van die totstandkoming van nog 'n Nederlandstalige koerant, Het Volksblad in 1856, maar ook omdat De Zuid-Afrikaan in kerklike sake 'n standpunt ingeneem het wat die meeste koloniste as te liberaal beskou het. Juis in hierdie jare was kwessies rakende kerk en godsdiens vir die Afrikaners in die kolonie van besondere belang en het hulle dikwels hieroor by openbare geleenthede en in die pers gedebatteer. ${ }^{4}$ Aangesien $\mathrm{Het}$ Volksblad ook 'n liberale teologiese standpunt gehad het, het 'n groepie ortodokse of konserwatiewe teoloë in Januarie 1862 nog 'n blad, naamlik De Volksvriend, opgerig. Jan Hendrik Hofmeyr, toe net 16 jaar oud, was van die begin af lid van die redaksie en het teen die einde van die jaar reeds die redakteur geword. ${ }^{5}$ Die blad het aanvanklik veral 'n teologiese inhoud gehad, maar geleidelik al meer die karakter van 'n algemene koerant aangeneem. In September 1871 het De Zuid-Afrikaan met De Volksvriend geamalgameer, ${ }^{6}$ met Hofmeyr as die eintlike redakteur. ${ }^{7}$ Hoewel Hofmeyr se konserwatiewe teologiese beskouing 'n deurslaggewende rol gespeel het in sy aanstelling as redakteur van De Volksvriend en later van De Zuid-Afrikaan, het hierdie beskouing net in enkele opsigte te make gehad met sy politieke denke, in besonder met die vraagstuk of die regering finansiële steun aan die kerk moes verskaf. ${ }^{8}$

omskryf word as almal wat die land bewoon en by implikasie blanke, bruin en swart inwoners insluit.

4. Hofmeyr en Reitz, Het Leven van Jan Hendrik Hofmeyr (Onze Jan), p 53; F.C.L Bosman en A. Dreyer, Hollandse Joernalistiek in Suid-Afrika gedurende die 19de Eeu en Lewenssketse van Hollandse Joernaliste in Kaapland (uitgewer nie vermeld, Kaapstad, 1930), pp 5-7; H. Giliomee, The Afrikaners: Biography of a People, 2nd edition (Tafelberg, Cape Town, 2009), p 208.

5. Hofmeyr en Reitz, Het Leven van Jan Hendrik Hofmeyr (Onze Jan), pp 53-62.

6. Die naam De Zuid-Afrikaan is behou, maar nog vir jare daarna het die woorde "vereenigd met De Volksvriend" op die voorblad verskyn.

7. Smuts het formeel ook nog redakteur gebly, maar het weens sy swak gesondheid nie werklik meer 'n redakteursrol vervul nie. Hy is in Mei 1873 oorlede en daarna was Hofmeyr amptelik die enigste redakteur. Vergelyk De Zuid-Afrikaan, 21 Mei 1873; A.P. van Niekerk, "Smuts, Jacques (Tjaak) Jean Henri (Hendrik)", in W.J. de Kock en D.W, Krüger (reds), Suid-Afrikaanse Biografiese Woordeboek, Volume 2 (Tafelberg, Kaapstad, 1972), pp 697-698.

8. Die verskille tussen die liberale en ortodokse denkrigtings in die kerk het veral oor sake rakende dogma en kerkregering gehandel. Die liberale teoloë was onder meer ten gunste daarvan dat die kerk nie meer finansiële steun van die regering moes kry soos vanaf die begin van die Nederlands Oos-Indiese Kompanjie se bewind aan die Kaap die geval was nie. Dit was 'n belangrike politieke strydpunt gedurende die 1860 's en 1870's in die Kaapkolonie en 'n groot deel van veral die Engelstalige koloniste wou die staatsteun beëindig. Dit het meegebring dat baie van diegene wat staatsfinansiering voorgestaan het, waaronder ook J.H. Hofmeyr, gekant was teen verantwoordelike bestuur vir die Kaapkolonie waar inwoners self oor sake soos hierdie sou besluit. Dit is ironies dat nadat verantwoordelike bestuur in 1872 verleen is, Hofmeyr juis een van die vernaamste beleidmakers in die kolonie geword het. Vergelyk De Zuid-Afrikaan, 1 Juni 1872; G.D. Scholtz, Die Ontwikkeling van die Politieke Denke van die Afrikaner, Volume 3, 1854-1881 (Perskor, Johannesburg, 1974), pp 311- 
In die 1870's is daar nog steeds in De Zuid-Afrikaan verwys na die "Hollandsche lezers", 9 maar dikwels ook na "Afrikaanders". ${ }^{10}$ Die blad was dan ook positief gesind teenoor die "Afrikaanderisme", waarmee bedoel is vaderlandsliefde en die bevordering van die Afrikaners se belange, ${ }^{11}$ en teenoor die Afrikanerbond, veral nadat hierdie liggaam in 1883 met die Zuid-Afrikaansche Boeren Beschermings Vereeniging geamalgameer is.

Die politieke, ekonomiese en sosiale verhoudinge tussen die verskillende bevolkingsgroepe in Suid-Afrika gedurende die negentiende eeu word behandel in verskeie wetenskaplike oorsigwerke. ${ }^{12}$ Hierdie artikel moet veral beskou word teen die agtergrond van die verhoudinge tussen die groepe in die Kaapkolonie. Daarom word enkele gegewens in hierdie verband verskaf. Teen 1840 het daar ongeveer 150 000 mense in die Kaapkolonie gewoon, waarvan 'n bietjie minder as die helfte van hoofsaaklik Europese afkoms was. Die oorgrote meerderheid van hulle was afstammelinge van mense wat in die vorige twee eeue na die kolonie geïmmigreer het en Nederlands of 'n vroeë vorm van Afrikaans as taal gebruik het. In die loop van die negentiende eeu het heelwat immigrante uit Groot-Brittanje na die gebied verhuis, maar die Nederlandstalige koloniste, of Afrikaners, het tot aan die einde van die eeu die meerderheid van die blanke bevolking gebly, hoewel hulle in die oostelike deel van die kolonie 'n minderheid teenoor die Engels- en anderstalige koloniste gevorm het. Teen 1840 was meer as die helfte van die inwoners mense wat afgestam het van die oorspronklike Khoisanbewoners van die gebied en van slawe wat vanaf die sewentiende eeu uit Afrika en Asië ingevoer is, en wat soms ook deur bloedvermenging gedeeltelik van Europese herkoms was. Na hierdie inwoners is reeds in die negentiende eeu in Engels as "coloureds" verwys is en hulle word vandag in Afrikaans meesal bruin mense genoem. ${ }^{13}$

Hoewel daar baie eienaars van sake-ondernemings en ook grondbesitters onder die bruin bevolking was, het 'n groot deel van hulle as arbeiders gewerk op

313; A. du Toit, “The Cape Afrikaners' Failed Liberal Moment, 1850-1870”, in J. Butler, R. Elphick and D. Welsh (eds), Democratic Liberalism in South Africa: Its History and Prospect (David Philip, Cape Town, 1987), pp 48-63.

9. Byvoorbeeld De Zuid-Afrikaan, 31 Augustus 1871.

10. Byvoorbeeld De Zuid-Afrikaan, 6 Juli 1872.

11. Vergelyk De Zuid-Afrikaan, 10 Augustus 1872.

12. Onder meer: R. Davenport and C. Saunders, South Africa: A Modern History (Macmillan, London, 2000); C. Hamilton, B.K. Mbenga and R. Ross (eds), The Cambridge History of South Africa, Volume 1, From Early Times to 1885 (University Press, Cambridge, 2010); R. Ross, A. Kelk Mager and B Nasson (eds), The Cambridge History of South Africa, Volume 2, 1885-1994 (University Press, Cambridge, 2012); F. Pretorius (red.), Geskiedenis van Suid-Afrika, van Voortye tot Vandag (Tafelberg, Kaapstad, 2012).

13. Demografiese gegewens word onder meer verskaf in R. Elphick and H. Giliomee, "The Origins and Entrenchment of European Dominance at the Cape, 1652-c.1840", in R. Elphick and H. Giliomee (eds), The Shaping of South African Society, 1652-1840, 2nd edition (Maskew Miller Longman, Cape Town, 1989), p 524; Giliomee, The Afrikaners, p 201. 
plase wat aan die koloniste behoort het en het hulle oor die algemeen die laer klas in die koloniale samelewing gevorm. ${ }^{14}$ Teen daardie tyd het nog maar min Bantoesprekende swart mense binne die grense van die kolonie gewoon. Hulle stamgebiede is geleidelik onder Britse beheer gebring, maar as aparte kolonies bestuur, totdat die een na die ander gebied by die kolonie ingelyf is. Dit het daartoe gelei dat die inwoners van Europese herkoms geleidelik 'n al kleiner minderheid in die kolonie geword het. Soos verder in die artikel blyk, is swart mense tydens Hofmeyr se redakteurskap van De Zuid-Afrikaan nog hoofsaaklik beskou as mense wat, weens die voortdurende grensoorloë en opstande wat nog tot in die 1880's voortgeduur het, vir die koloniste 'n bedreiging was. Die blad het die inlywing van die stamgebiede by de kolonie gesien as 'n oplossing vir onrus en geweld in die gebied. Eers na 1883 het die Afrikaners die getallemeerderheid van swart mense in die kolonie as 'n probleem begin beskou.

Gedurende die eerste jare nadat die Kaapkolonie in 1806 onder Britse bewind gekom het, was die bestuurstelsel outokraties, maar reeds vanaf die 1820s het die koloniste hul beywer vir inspraak in die koloniale bestuur. Die Wetgewende Raad, wat in 1834 ingestel is, was nie 'n verkose liggaam nie, maar in 1854 is 'n grondwet vir die kolonie aanvaar waarvolgens die inwoners self 'n Wetgewende Vergadering verkies het. Eers in 1872 is verantwoordelike bestuur ingestel, waarvolgens die interne bestuur van die kolonie by 'n parlement en 'n kabinet, bestaande uit inwoners van die kolonie, berus het. Toe daar in die aanloop tot die aanvaarding van die grondwet van 1854 op stemregvereistes besluit is, is 'n besitskwalifikasie aanvaar, wat dus meegebring het dat inwoners van alle bevolkingsgroepe wat aan die vereistes voldoen het stemreg gehad het. ${ }^{15}$ Dit was in ooreenstemming met die beleid van die Britse regering en is ook in ander kolonies toegepas. Die Kaapkolonie se stemregvereistes het tog groter deelname as wat in die meeste ander kolonies die geval was moontlik gemaak van inwoners wat nie koloniste of "Europeërs" was nie.

Hierdie stemregbepalings is reeds in 1853 in De Zuid-Afrikaan en ook deur latere historici, as "liberaal" bestempel. ${ }^{16}$ Die liberale denke van die agtiende-eeuse Verligting in Europa het dan ook 'n invloed op die aard van die grondwet en veral die stemregkwalifikasies gehad. Liberale beskouinge was slegs in beperkte mate aanwesig onder die koloniste, sowel Engels- as Afrikaanssprekend, maar blyk, soos verder aangetoon sal word, tog in hoofartikels van De Zuid-Afrikaan. Met die term

14. Vergelyk Elphick and Giliomee, "Origins and Entrenchment of European Dominance at the Cape", pp 521-566, waarin aangetoon word hoe die blanke koloniste in die loop van die agtiende en vroeë negentiende eeue hul as dominerende groep in die kolonie op sosiale en ekonomiese gebied gevestig het.

15. S. Trapido, "The Origins of the Cape Franchise Qualifications of 1853", Journal of African History, 5, 1 (1964), pp 37-54; P. de Klerk, "De Zuid-Afrikaan se Standpunt oor Stemreg vir Bruin Mense voor die Totstandkoming van die Kaapse Koloniale Parlement in 1854", Historia, 59, 1 (2014), pp 1-17.

16. J. Evans, P. Grimshaw, D. Philips and S. Swain, Equal Subjects, Unequal Rights: Indigenous Peoples in British Colonies, 1830-1910 (University Press, Manchester, 2003), p 1; De Zuid-Afrikaan, 5 Mei 1853. 
"liberale tradisie" wat in later jare deur akademici en politici ten opsigte van die Kaapkolonie gebruik is, het hulle dikwels veral die stemreg in gedagte gehad, maar dit het ook ingehou dat amptelik nie op rassegronde gediskrimineer is in die regstelsel en in wetgewing nie. Hierdie tradisie is nie net van Britse oorsprong nie. Reeds in die laat agtiende eeu kom daar liberale beskouinge onder leidende Kaapse koloniste voor en dit was ook die geval in die negentiende eeu. ${ }^{17}$

De Zuid-Afrikaan se algemene beskouinge en uitsprake oor die bruin en swart mense in die Kaapkolonie in die periode voor 1871 word hieronder kortliks bespreek, in besonder om te bepaal in hoeverre Hofmeyr aansluit by die koers wat sy voorgangers ingeslaan het. Daarna word kommentaar in redaksionele artikels gedurende die periode 1871-1883 behandel oor bepaalde sake wat bruin en swart mense geraak het, naamlik stemreg, militêre diens, arbeid, onderwys en regeringsbeleid ten opsigte van swart mense in die grensgebiede van die kolonie. Hoewel Hofmeyr waarskynlik nie al die hoofartikels self geskyf het nie, was hy as redakteur verantwoordelik vir die inhoud daarvan en kan aanvaar word dat wanneer die artikels saam bekyk word, sy beskouinge daarin weerspieël word.

\section{De Zuid-Afrikaan se beskouinge oor bruin en swart mense in die kolonie gedurende die tydperk 1830-1871}

Die hoofartikels van De Zuid-Afrikaan in die tydperk 1830-1871 handel oor 'n groot verskeidenheid sake, waarvan net 'n klein gedeelte met die bruin en swart inwoners van die Kaapkolonie te make het. Reeds tydens die eerste jare verklaar die blad hom ten gunste van 'n beleid wat daartoe lei dat die inheemse bevolking van die kolonie uit hul "ruwen en onbeschaafde toestand" opgehef word sodat hulle uiteindelik hul plek as volwaardige burgers in die koloniale samelewing kan inneem. ${ }^{18}$ Die optrede van dr. John Philip en ander "philantropisten" wat "overluid over onregtvaardige, onmenschlievende en wrede behandeling hebben geschreeuwd" word egter skerp veroordeel. ${ }^{19}$ Die koerant meen dat die pogings van sendelinge van veral die Londense Sendinggenootskap om die swart mense te probeer "beskaaf" sal misluk omdat hulle "aan den verkeerden kant begonnen zijn ... zij trachten hen eerst te heiligen, vermeenende dat beschaving van zelf volgen moet". ${ }^{20}$ Voor 1871 het daar nie 'n groot aantal Bantoesprekende swart mense binne die koloniale grense gewoon nie, en het artikels waarin die swart mense ter sprake kom veral gehandel oor

17. P. de Klerk, "Afrikanerliberalisme in die Tydperk 1775-1975: Die Interpretasies van G.D. Scholtz en H. Giliomee”, The Journal for Transdisciplinary Research in Southern Africa, 7, 2 (2011), pp 139-158. Vergelyk ook S. Trapido, 'The Friends of the Natives', Merchants, Peasants and the Political and Ideological Structure of Liberalism in the Cape, 1854-1910", in S. Marks and A. Atmore (eds), Economy and Society in Preindustrial South Africa (Longman, London, 1980), pp 247-274; en R. Davenport, "The Cape Liberal Tradition to 1910", in Butler, Elphick and Welsh, Democratic Liberalism in South Africa, pp 21-34.

18. De Zuid-Afrikaan, 23 Maart 1832.

19. De Zuid-Afrikaan, 23 Maart 1832.

20. De Zuid-Afrikaan, 1 Februari 1847. 
botsings met stamme in die oostelike grensgebied van die kolonie. Na hierdie groepe word deurgaans as barbare of "wilden" verwys. ${ }^{21}$ Reeds in 1856 verklaar De ZuidAfrikaan dat die probleme met die swart stamme slegs opgelos kan word as die stamme opgebreek en in klein groepies onder die koloniste gevestig word, sodat hulle geleidelik "beskaaf" en deel van die koloniale samelewing gemaak kan word. ${ }^{22}$

Daar het in die periode 1830-1871 verskeie artikels verskyn wat gehandel het oor probleme rakende "leegloopers en vagabonden" in landelike gebiede, ${ }^{23}$ maar ook oor plakkers in Kaapstad en ander dorpsgebiede. Die plakkers word in een van die hoofartikels selfs bestempel as "verlaagde staaltjes der menschheid, welke zamenscholen in die verpestende woonsteden, pondokken genoemd". Die pondokke word beskryf as "holen van vuiligheid, zedelooheid en dronkenschap". ${ }^{24}$ In sommige artikels word in positiewe sin oor die bruin mense geskryf en veral die Maleierbevolking van die stad geprys vir hul goeie gedrag, lojaliteit en werkywer. ${ }^{25}$ Die koerant was dan ook ten gunste van die betreklik lae eiendomskwalifikasie vir stemreg in die koloniale grondwet van 1853 waardeur 'n gedeelte van die bruin mense saam met die oorgrote meerderheid blankes aan verkiesings vir die koloniale parlement kon deelneem. ${ }^{26}$ In die artikels na September 1871 oor sake rakende bruin en swart mense kom sterk kontinuïteit met De Zuid-Afrikaan se vroeëre beskouinge oor hierdie sake na vore.

\section{Stemreg}

De Zuid-Afrikaan het in 1853 die instelling van 'n koloniale grondwet met lae eiendomskwalifikasies verwelkom, nie alleen omdat dit beteken het dat die meeste blanke Afrikaanse of Nederlandstalige inwoners stemreg sou hê nie, maar ook omdat 'n gedeelte van die bruin mense in die kolonie as kiesers sou kon kwalifiseer. ${ }^{27}$ 'n Probleem wat in daardie tyd blykbaar nie voorsien is nie, sou in latere jare na vore kom, naamlik dat heelwat kiesers, veral onder "het onkundige gedeelte der bevolking", ${ }^{28}$ omgekoop kon word om vir 'n bepaalde kandidaat te stem. Daar was in daardie jare nog geen geheime stemming met stembriefies soos tans die geval is nie, en by verkiesings het kiesers mondeling aan verkiesingsbeamptes verklaar vir wie hul wou stem. ${ }^{29}$ In 1874 skryf De Zuid-Afrikaan, in 'n taamlik neerhalende trant, dat

21. De Zuid-Afrikaan, 1 Februari 1847; 3 Mei 1852; 15 Januari 1855; 10 Oktober 1859; 13 Juli 1865; 4 Maart 1867; 1 September 1870.

22. De Zuid-Afrikaan, 14 Augustus 1856.

23. De Zuid-Afrikaan, 23 November 1832; 5 Oktober 1838; 3 Mei 1839; 30 Maart 1848; 13 Juni 1867.

24. De Zuid-Afrikaan, 14 Januari 1856; vergelyk De Zuid-Afrikaan, 26 Juni 1865.

25. De Zuid-Afrikaan, 6 November 1840; 11 Augustus 1853; 1 Mei 1871.

26. Vergelyk De Klerk, "De Zuid-Afrikaan se Standpunt oor Stemreg vir Bruin Mense voor die Totstandkoming van die Kaapse Koloniale Parlement in 1854", pp 1-17.

27. De Zuid-Afrikaan, 5 Mei 1853.

28. De Zuid-Afrikaan, 1 Juni 1872.

29. J.L. McCracken, The Cape Parliament, 1854-1910 (Clarendon Press, Oxford, 1967), pp 32-70, behandel die verkiesingsprosedures wat in die Kaapkolonie gevolg is en toon 
toe die deure van die stemkantore by 'n verkiesing in Kaapstad geopen het, "een gansch heirleger van Abdols, Abdoellahs, en de heffe des volks" daar ingestorm het. ${ }^{30}$ In 1880 word geskryf dat dit 'n skande is dat "praktisch elke stinkende Mozambieker of kale Boschjesman, of met roode klei besmeerde Kaffer" 'n gelyke stem het met mense van "allerbeschaafdste opvoeding" en met groot grondeienaars, maar word tog aangedui dat stemregmisbruik nie 'n rasseprobleem is nie, maar eerder ' $n$ klasseprobleem en dat omkopery van kiesers ook in Groot-Brittanje voorkom. Die "onkundige" kiesers is nie net bruin en swart mense nie, maar sluit ook blankes in. ${ }^{31}$ Stemwerwers het blykbaar daarvoor gesorg dat groot getalle mense van die "onkundige klas" op kieserslys kom, terwyl baie grondbesitters hul nie as kiesers laat registreer het nie. Selfs persone wat nie aan die stemregvereistes voldoen het nie is soms op lyste geplaas. Derhalwe het De Zuid-Afrikaan daarvoor gepleit dat die registrasie van kiesers strenger beheer en maatreëls om omkopery te bekamp ingestel word. ${ }^{32}$

De Zuid-Afrikaan het hom reeds voor 1871 in verskeie uitgawes ten gunste van hoër eiendomskwalifikasies uitgespreek ${ }^{33}$ en in 1877 opvoedingskwalifikasies as 'n moontlike alternatief vir die bestaande stelsel gesien, veral om te verhoed dat in 'n suider-Afrikaanse konfederasie, wat toe in die vooruitsig gestel is, inheemse "kombaars en karosdragers" die meeste verteenwoordigers in 'n federale parlement sou kry. ${ }^{34}$ Die blad verklaar dat hy graag sou wou sien dat opgeleide Maleise en swart vakmanne en onderwysers stemreg het, maar wys daarop dat hoë opvoedingskwalifikasies ook heelwat blankes sou uitsluit. ${ }^{35}$ Enkele jare later skryf die koerant dat 'n opvoedingstoets moeilik toepasbaar is en dat wysigings in stemregvereistes nie die probleem van omkopery sal oplos nie. Hoër kwalifikasies sal eerlike armes uitsluit en net tot meer bedrog lei. ${ }^{36}$ De Zuid-Afrikaan was veral daaroor bekommerd dat as 'n beduidende aantal Afrikaners verandering in stemregvereistes voorstaan, Engelstalige koerante en politici so 'n standpunt sal gebruik om bruin mense te oortuig dat die Afrikaners hul van parlementsverteenwoordiging wil uitsluit en dat hul heil derhalwe eerder by die Engelstalige as die Nederlandstalige koloniste sou lê. ${ }^{37}$

onder meer aan dat werkers soms deur hul werkgewers onder druk geplaas is om vir 'n bepaalde kandidaat te stem.

30. De Zuid-Afrikaan, 4 Februarij 1874. Die woord "heirleger" beteken 'n groot menigte. Die "Abdols en Abdoellahs" verwys na die Maleierbevolking, onder wie hierdie name algemeen voorkom, terwyl die uitdrukking "heffe des volks" vertaal kan word as die gepeupel.

31. De Zuid-Afrikaan, 28 Januari 1880.

32. De Zuid-Afrikaan, 28 Januari 1880.

33. Onder meer De Zuid-Afrikaan, 15 Mei 1854; 17 Januari 1859’ 2 Mei 1867.

34. De Zuid-Afrikaan, 14 Februari 1877.

35. De Zuid-Afrikaan, 14 Februari 1877.

36. De Zuid-Afrikaan, 28 Januari 1880.

37. De Zuid-Afrikaan, 5 Januari 1882, 4 November 1882, 7 November 1882. 
In 1882 skryf De Zuid-Afrikaan dat die Zuid-Afrikaansche Boeren Beschermingsvereeniging in die Wes-Kaap, wat in 1878 veral deur Hofmeyr se toedoen tot stand gekom het en wat hom onder meer beywer het vir die bevordering van die Afrikaanstalige boere se belange in die parlement, meer aandag moet gee aan bruin mense as politieke mag by verkiesings en voorkom dat 'n anti-Afrikaanse sentiment onder hulle aangeblaas word. Dit geld ook vir ander boereverenigings wat hoofsaaklik in die oostelike dele gestig is. ${ }^{38}$ Die verenigings moet aantoon dat "Afrikaanderisme" ook in belang van die bruin mense is. ${ }^{39}$ In 'n latere artikel word die Oranje-Vrystaatse bestuur van die Afrikanerbond gekritiseer omdat dit ' $n$ bepaling in sy konstitusie opgeneem het wat lidmaatskap tot blankes beperk het. Dit sou beter wees as daar geen bepalings oor kleur was nie en die toelating van lede aan wyksbesture oorgelaat word. Op hierdie wyse sou "mannen van terugstootende kleur - hetzij ligchamelijke of zedelijke" wel uitgesluit kon word. ${ }^{40}$

De Zuid-Afrikaan het dus in die jare 1871 tot 1883 kritiek gelewer op wanpraktyke in die stemregstelsel en in 1877 die instelling van opvoedingskwalifikasies bepleit, maar hom nie teen die beginsel van nie-rassige stemreg uitgespreek nie. In 1883 het die blad selfs gevra dat blankes en ook bruin mense, naamlik "de Griqua's zelve en de gekleurde landeigenaars" in GriekwalandOos, wat in 1879 by die Kaapkolonie ingelyf is, verteenwoordiging in die Kaapse koloniale parlement kry.41

\section{Militêre diens}

In die agtiende eeu het 'n militêre verdedigingstelsel in die Kaapkolonie ontwikkel waarvolgens koloniste in kommando's georganiseer en, veral in die grensgebiede, in konflikte met die San of Boesmans en die Xhosa aangewend is. Bruin mense het van die begin af deel van die kommandostelsel gevorm. ${ }^{42}$ In 1878 is wetgewing aanvaar om die stelsel te herorganiseer, en toe daar in 1880 onrus in Basutoland en die Xhosastamgebiede uitbreek, is inwoners van die kolonie weer ingespan om militêre diens te verrig. ${ }^{43}$ Nadat ongeveer driehonderd vrywilligers onder die bruin mense van die Wes-Kaap per skip na die Oos-Kaap gestuur is, het De Zuid-Afrikaan die

38. Vergelyk Davenport, The Afrikaner Bond, 1880-1911, pp 14-27.

39. De Zuid-Afrikaan, 7 November 1882.

40. In die praktyk het lidmaatskap van die Afrikanerbond tot blankes beperk gebly. Vergelyk Davenport, The Afrikaner Bond, 1880-1911, p 329.

41. De Zuid-Afrikaan, 5 Julij 1883. Vergelyk De Zuid-Afrikaan, 12 Juli 1883.

42. Die stelsel is amptelik in 1833 afgeskaf, maar daarna is inwoners van die kolonie nog opgeroep om, op vrywillige basis, in konflikte aan die oosgrens militêre diens te doen. Vergelyk P.E. Roux, “Die Geskiedenis van die Burgerkommando's in die Kaapkolonie, 1652-1878”, D.Phil.-proefskrif, Universiteit van Stellenbosch, 1946, veral pp 360-386, 402-405; M. Legassick, "The Northern Frontier to c. 1840: The Rise and Decline of the Griqua People", in Elphick and Giliomee, The Shaping of South African Society, pp 361, 373.

43. De Zuid-Afrikaan, 11 November 1880; Davenport and Saunders, South Africa: A Modern History, p 146. 
militêre owerhede se behandeling van hierdie mense skerp gekritiseer. Onder meer is die reëlings vir hul vertrek so swak getref dat hulle nie die kans gegun is om van hul familie afskeid te neem nie en daar is geen voorsiening gemaak vir die besondere vereistes waaraan voedsel vir Moslems moes voldoen nie. Die artikel sluit af met die woorde "zelfs kleurlingen zijn mensen". ${ }^{44}$ Die blad was egter daarteen gekant dat "kleurlingen en blanken, den baas en diens knecht, op gelijke voet" in dieselfde militêre eenhede diens doen. ${ }^{45}$

\section{Arbeid}

Daar is in die periode 1871-1883 dikwels in De Zuid-Afrikaan geskryf oor arbeidstekorte. In 1872 word gemeld dat daar in die kolonie 'n tekort is aan huisbediendes en ook aan veeherders en ander plaasarbeiders. Tegelykertyd het die boere te kampe met veediefstal, wat volgens die koerant daarop dui dat daar heelwat mense is wat liewer wil steel as werk. De Zuid-Afrikaan meen egter dat wetgewing om "inlanders" (dit wil sê swart mense en mense van Khoikhoiherkoms) te dwing om hulle aan 'n "meester te verbinden", soos deur sommige inwoners van die kolonie voorgestaan word, nie 'n goeie oplossing vir die probleem sal wees nie, want "zulke wetten kunnen geen luijen kaffer of hottentot hervormen tot een bruikbaar arbeider". As meesters toegelaat word om hul arbeiders te straf, kan dit lei tot 'n nuwe vorm van slawerny, en verder kan dit meebring dat "inlanders" uit die kolonie padgee. ${ }^{46}$ In 'n latere uitgawe word tog verklaar dat onrus op die noordgrens van die kolonie bekamp behoort te word deur, onder meer, "Boschjesmans en andere rondloopers van dergelijke soort" as werkers by boere in te boek. ${ }^{47}$ Dit lyk vir De Zuid-Afrikaan nie na 'n geskikte oplossing vir die arbeidsprobleem om mense uit Europa as arbeiders in te voer nie, aangesien hulle sulke hoë lone betaal sal moet word dat die meeste boere dit nie sal kan bekostig nie. Die blad wys tog ook daarop dat Australiese boere wel hoë lone vir arbeiders wat uit Europa afkomstig is betaal en meen dat, as Kaapse boere maatreëls tref soos om die kwaliteit van hul wol te verhoog, hulle moontlik wel Europese arbeiders sal kan bekostig. ${ }^{48}$ In 'n latere uitgawe skryf die koerant dat baie bruin mense wat op plase gewerk het, beter werkgeleenthede in, onder meer, die vervoerbedryf gekry het. Om hoër lone aan bruin plaasarbeiders te betaal, lei egter ook tot probleme, aangesien baie van "de hand naar den tand" leef en ophou werk as hulle dink dat hulle genoeg geld gemaak het. Dit is 'n probleem wat ook onder arbeiders in Engeland voorkom. ${ }^{49}$

In die jare vanaf 1874 bepleit De Zuid-Afrikaan die invoer van arbeiders uit China en Indië as oplossing vir die probleem van arbeidstekorte. ${ }^{50}$ Die blad gee toe dit

44. De Zuid-Afrikaan, 11 November 1880. Vergelyk De Zuid-Afrikaan, 16 December 1880.

45. De Zuid-Afrikaan, 31 Januari 1882. Vergelyk De Zuid-Afrikaan, 2 Februari 1882.

46. De Zuid-Afrikaan, 19 Oktober 1872.

47. De Zuid-Afrikaan, 15 November 1883.

48. De Zuid-Afrikaan, 19 Oktober 1872.

49. De Zuid-Afrikaan, 13 September 1873; vergelyk De Zuid-Afrikaan, 20 Juni 1874.

50. De Zuid-Afrikaan, 20 Juni 1874; 11 December 1875; 24 Juni 1876. 
sou "inderdaad jammer zijn, nog een ander ras toe te voegen aan de reeds bontgemengde bevolking der Kaapkolonie", maar meen dat Chinese arbeiders hul nie permanent in die land sal vestig nie. Hoewel bruin mense, waaronder veral die Maleiers, en ook "sommige der laagste klassen van Europesche immigranten" gekant sal wees teen die invoer van Chinese, sal die feit dat die bestaande arbeiders met hul sal moet meeding juis tot groter werkywer onder hulle lei. Daarom behoort 'n aantal Chinese arbeiders, ten minste as proefneming, ingevoer te word. ${ }^{51}$ In 1879 verwelkom die koerant die moontlike invoer van Bergdamaras uit Damaraland en "Delagoabaaische negers" oor wie se eienskappe as arbeiders gunstige berigte ontvang is. ${ }^{52}$ Toe dit blyk dat die boere nie baie gretig was om arbeiders uit Mosambiek in diens te neem nie, verskaf die blad die onjuiste inligting dat die Mosambiekers wel "Kaffers" genoem word, maar baie verskil van die swart mense in die oostelike Kaapkolonie omdat hulle Arabiese bloed het en eintlik tot "een gansch ander ras" behoort. ${ }^{53}$ Wat betref Suid-Afrikaanse swart mense, veral Zulusprekendes, wat uit gebiede van buite die Kaapkolonie ingevoer is, meld De Zuid-Afrikaan dat hulle geblyk het nie baie geskikte plaasarbeiders te wees nie en hierin sien die blad aanvanklik geen oplossing vir die arbeidsprobleem nie. ${ }^{54}$ In 'n latere uitgawe word die invoer van swart mense van buite die Kaapkolonie tog voorgestaan veral vir werk op die spoorweë, omdat hulle nie maklik sal wegloop nie en so 'n maatreël daartoe sal lei dat meer bruin mense vir arbeid op boereplase beskikbaar is. ${ }^{55}$ Die verwestering of "beskawing" van swart mense, wat deur De Zuid-Afrikaan voorgestaan is en in 'n volgende afdeling verder bespreek word, maak dit verder wenslik dat ook swart mense van binne die kolonie aangemoedig moet word om arbeiders op blanke plase te word. ${ }^{56}$

De Zuid-Afrikaan wys daarop dat baie Afrikaners meen dat dit vernederend is om hulself as hande-arbeiders te verhuur. Skole moet help om hierdie wanopvatting teen te werk, sodat dit "geen ongewone zaak wordt" om lede van "onze beste, maar verarmde families ... als knecht te zien arbeiden op boerderij of werkplaats". Terselfdertyd moet bruin mense op skool leer dat hande-arbeid nie 'n teken van onderwerping aan die blankes is nie. ${ }^{57}$ Laasgenoemde uitlating is moeilik te rym met 'n uitspraak in 'n vroeëre hoofartikel, naamlik dat in 'n land waar die diensknegte tot "een barbaarsch ras" behoort en 'n heel ander lewensuitkyk het as hul meesters, soos in die Kaapkolonie die geval is, die wette en die toepassing daarvan van so ' $\mathrm{n}$ aard moet wees dat die diensknegte sal besef dat hulle nie die gelykes van hul meesters is nie. Die blad verklaar dat hy in die algemeen nie "den Naturel ${ }^{58}$... voor minder dan

51. De Zuid-Afrikaan, 13 Augustus 1879; vergelyk De Zuid-Afrikaan, 16 Februari 1882.

52. De Zuid-Afrikaan, 1 November 1879; vergelyk De Zuid-Afrikaan, 12 November 1879.

53. De Zuid-Afrikaan, 26 November 1879.

54. De Zuid-Afrikaan, 19 Januari 1876.

55. De Zuid-Afrikaan, 16 Februari 1882.

56. De Zuid-Afrikaan, 7 Augustus 1883.

57. De Zuid-Afrikaan, 14 Oktober 1882.

58. Die term naturel verwys hier nie net na Bantusprekende swart mense nie, maar ook na mense van Khoikhoiherkoms. 
den blanke" hou nie, en dat daar bruin mense is wat "eigenen plaatsen en een vrij aanzienlijk vermogen" het. Daar is geen rede om hierdie mense "bij den blanken achter te stellen" nie, maar iemand wat "tot de dienende klasse behoort moet leeren dat zoolang hij dient hij de mindere is". ${ }^{9}$

In verskeie uitgawes van De Zuid-Afrikaan word boere verdedig teen klagtes dat hulle hul werkers nie goed behandel nie en in 1876 word geskryf dat koloniale wette dit makliker maak vir werkers wat klagte teen meesters wil lê as andersom. ${ }^{60}$ Die blad meen ook dat Afrikaanse boere geensins 'n slegter verhouding met hul arbeiders het as Engelssprekende boere nie en dat "de Afrikaansche boer veelal beter dan de Engelsche er in slaagt de harten zijner onderhoorigen te winnen". ${ }^{61}$ De ZuidAfrikaan is dan ook van mening dat veral in die westelike dele van die kolonie, waar daar nie botsinge met swart mense in die grensgebiede is nie (en waar daar meer Afrikaanse as Engelse boere was), daar oor die algemeen nie 'n groter onderskeid en groter spanning tussen hoër en laer klasse voorkom as in Europa nie. ${ }^{62}$

\section{Onderwys}

Daar word gedurende die periode 1871-1883 slegs in enkele redaksionele artikels na onderwys vir bruin mense verwys, terwyl daar oor onderwysinstellings wat vir swart mense in die oostelike dele van die kolonie opgerig is feitlik geen kommentaar gelewer word nie. In 'n artikel oor Rooms-Katolieke en Protestantse kerkskole in Kaapstad word geskryf dat hierdie skole as sendingskole beskou kan word en veral ten doel het om kinders van die straat af te hou en "de lagere klassen voor de kerk te behouden" eerder as om leerlinge "voor de maatschappij te bekwamen". Die "laagste volksklassen" sal moontlik hiermee tevrede wees omdat hulle daarmee hul kinders "uit het pad" kry, maar "de armere middelklassen - klerken en fatsoenlijke ambachtslieden" sal wil sien dat hul kinders opgelei word om beroepe soos winkelbediendes en kantoorklerke te beoefen. Hulle sal ook nie wil hê dat hul kinders in aanraking kom met "een digten drom van Maleische en andere kleurlingkinderen" nie. ${ }^{63}$ Hieruit kan afgelei word dat De Zuid-Afrikaan onder die "armere middelklassen" hoofsaaklik blankes op die oog het en nie eintlik begaan is oor gebreke in die onderwys vir bruin mense nie. In 'n latere artikel vereenselwig die blad hom met klagtes dat onderwys op sommige sendingskole daartoe lei dat bruin mense wat daar opgelei is neersien op hande-arbeid. ${ }^{64}$ Daar was in hierdie periode verskillende soorte skole wat staatsteun ontvang het. Skole waarin onderrig gegee is wat tot meer gevorderde opleiding (dit wil sê tot sekondêre skoolvlak en verder) kon

\footnotetext{
59. De Zuid-Afrikaan, 16 Mei 1882.

60. De Zuid-Afrikaan, 26 April 1876; vergelyk De Zuid-Afrikaan, 16 Mei 1882.

61. De Zuid-Afrikaan, 4 November 1882.

62. De Zuid-Afrikaaan, 6 September 1883.

63. De Zuid-Afrikaan, 8 September 1875.

64. De Zuid-Afrikaan, 14 Oktober 1882.
} 
lei, is hoofsaaklik deur blankes bygewoon, ${ }^{65}$ maar De Zuid-Afrikaan het hom uitgespreek teen pogings om bruin mense uit hierdie skole te hou. Ter motivering van sy standpunt verklaar die blad onder meer dat dit nie altyd moontlik is om te bepaal wie blank en wie gekleurd is nie.66

\section{Regeringsbeleid ten opsigte van swart mense in die koloniale grensgebiede}

In die loop van die negentiende eeu het die Kaapkolonie steeds verder ooswaarts uitgebrei en het al meer Bantusprekende swart mense inwoners van die kolonie geword. In 1866 is die gebied tussen die Keiskamma en die Keirivier, wat eers 'n aparte Britse kolonie was, by die Kaapkolonie ingelyf en in 1879 ook Fingoland en Griekwaland-Oos. Die grootste deel van die gebied wat later as die Transkei bekend geword het, was teen 1883 egter nog nie deel van die kolonie nie. ${ }^{67}$

De Zuid-Afrikaan het die groot meerderheid swart mense wat in die oostelike grensgebied van die kolonie gewoon het en al die inwoners van die ongekoloniseerde gebied verder ooswaarts, ook nog na 1871 as "wilden" of barbare beskou. ${ }^{68}$ In 1877 het 'n oorlog met die stamme wat in die gebied oos van die Kaapkolonie gewoon het uitgebreek (die sogenaamde Negende Grensoorlog), waarna ook groepe binne die grense van die kolonie in opstand gekom het. Dit het De Zuid-Afrikaan laat opmerk dat op 'n gegewe moment het "gansche Kafferdom als één man naar de wapens" gryp, "het barbaarsche zowel als het christelijke, het witgedaste en zwartgemanelde zowel als het kale en in karossen gehulde". Ten spyte van vooruitgang en beskawing onder 'n gedeelte van die swart mense kry "nationale eensgezindheid en nationale haat" voorrang bo ander oorwegings en emosies onder hulle. ${ }^{69}$ Dit laat die vraag ontstaan of op die lojaliteit van enige swart mense staat gemaak kan word en enige van hulle toegelaat kan word om vuurwapens te besit. ${ }^{70}$ Dit blyk uit latere artikels dat die koerant meen dat grootskaalse vestiging van blankes in die stamgebiede en gepaardgaande verwestering van swart mense sal help om hierdie vraagstuk op te los.

De Zuid-Afrikaan was steeds ten gunste daarvan dat die swart mense in die kolonie verwesters of "beskaaf" moet word. Die blad argumenteer dat dit nie 'n algemene reël is dat beskawing oor barbarisme triomfeer nie. Daar is in die wêreldgeskiedenis voorbeelde waar die teenoorgestelde gebeur het. Daarom kan die koloniste nie "onverschillige en tijdelijke toeschouwers zijn van de afschuwelijkheden van het woeste leven der barbaarsche stammen" rondom hulle nie. Hulle moet of "in den naam der menschelijkheid tusschen beiden komen òf zelven in de schaal der

65. Vergelyk A.L. Behr and R.G. Macmillan, Education in South Africa, 2nd edition (Van Schaik, Pretoria, 1971), p 114.

66. De Zuid-Afrikaan, 9 November 1882.

67. Basutoland, tans Lesotho, was van 1871 tot 1884 deel van die Kaapkolonie. Vergelyk Davenport and Saunders, South Africa: A Modern History, pp 105, 145, 160, 161.

68. De Zuid-Afrikaan, 12 April 1873; 16 Oktober 1875.

69. De Zuid-Afrikaan, 5 Januari 1878.

70. De Zuid-Afrikaan, 8 Januari 1879. 
humaniteit dalen". Aangesien dit die taak van die inwoners van die kolonie is om die stamme te "beskaaf", kan dit nie aan die Britse regering oorgelaat word om die stamme tussen de Kaapkolonie en Natal te beheer nie, maar moet die koloniale regering die verantwoordelikheid op hom neem. ${ }^{71}$ Die Britte weet immers nie beter as die koloniste self hoe die verhouding tussen die inheemse bewoners en die koloniste gereël moet word nie. ${ }^{72}$

Om die beskawingstaak suksesvol te kan uitvoer moet soveel moontlik blankes in die gebiede wat nog uitsluitlik deur swart mense bewoon is, gevestig word. In verskeie uitgawes verklaar die blad homself ten gunste van die vestiging van groot groepe blanke immigrante in swart stamgebiede. ${ }^{73}$ Grootskaalse vestiging van blankes in die oostelike grensgebiede kan daartoe lei dat uiteindelik 'n soortgelyke toestand bereik word as in die westelike deel van die kolonie, waar die blanke bevolking die toon aangee en "de maatschappelijke betrekkingen regelt, zonder dat haar gekleurde mede-inwoners des lands er bij lijden". Anders sal dit lei tot 'n samelewing soos in Indië en ook in Natal "waar alles op Naturellenmanier is ingerigt", selfs al behartig blanke amptenare die bestuur. ${ }^{74}$ Die blad sal nie graag wil sien dat immigrante uit Rooms-Katolieke lande tussen die swart stamme gevestig word nie. Dit sou daartoe kon lei dat die swart mense vir die Rooms-Katolisisme gewen word en polarisasie volgens godsdiensverskille in die kolonie ontstaan en moontlik ook dat die Protestante 'n minderheid in die kolonie word. ${ }^{75}$ Aan die ander kant sou "beschaafde en nijvere kleurlingen" in die kolonie wel geskik wees vir vestiging tussen die Bantusprekende stamme. ${ }^{76}$ Die koerant verwerp besware dat grond waarop swart stamme woon nie van hulle afgeneem mag word nie. Dit is die enigste manier waarop blanke kolonisasie kan geskied en in Suid-Afrika "voor zover het voor blanken bewoonbaar is" 'n blanke bevolking gevestig kan word. ${ }^{77}$ Dit is van die grootste belang om die swart mense "even zeer tot leden der Kolonisten maatschappij te maken als de Westelijke kleurlingen het reeds zijn"; die toekoms van Suid-Afrika hang daarvan af. ${ }^{78}$

\section{Slotbeskouing}

By die beoordeling van Hofmeyr se beskouinge oor sake rakende bruin en swart mense, soos dit in hoofartikels in De Zuid-Afrikaan na vore kom, moet sy denke binne

71. De Zuid-Afrikaan, 20 Augustus 1879.

72. De Zuid-Afrikaan, 17 Mei 1883. In 1880 (De Zuid-Afrikaan, 2 Oktober) skryf die blad tog dat dit om finansiële redes beter is as die Britse regering die gebied tussen die Keirivier en Natal bestuur. Dit is nie in ooreenstemming met die argumentasielyn in die ander artikels nie

73. De Zuid-Afrikaan, 28 Maart 1882; 13 April 1882; 8 Juni 1882; 15 Juni 1882, 14 September 1882; 21 April 1883.

74. De Zuid-Afrikaan, 21 April 1883.

75. De Zuid-Afrikaan, 10 Juni 1882.

76. De Zuid-Afrikaan, 3 April 1883; vergelyk De Zuid-Afrikaan, 21 April 1883.

77. De Zuid-Afrikaan, 14 September 1882.

78. De Zuid-Afrikaan, 7 Augustus 1883. 
die konteks van politieke strominge en denkrigtinge in die Kaapkolonie gedurende die tweede helfte van die negentiende eeu bekyk word. Daar was in die Kaapse koloniale parlement aanvanklik geen politieke partye nie en die Afrikanerbond, wat gestig is in 1879, en waarvan Hofmeyr teen 1883 die leidende figuur geword het, word gewoonlik as die eerste politieke party in Suid-Afrika beskou. ${ }^{79}$ Hierdie beweging het hom, soos die naam aandui, in besonder vir die belange van die Afrikaners beywer. Verhoudinge tussen die blanke, bruin en swart bevolkingsgroepe sou eers in die tweede helfte van die twintigste eeu die dominerende vraagstuk in die Suid-Afrikaanse politiek word. Wanneer die terme liberaal en konserwatief ten opsigte van die negentiende-eeuse Kaapse politiek gebruik is, het dit vir besondere sake gegeld, soos die verlening van verantwoordelike bestuur aan die kolonie. ${ }^{80}$ In $D e$ Zuid-Afrikaan word die begrippe konserwatief en liberaal ook nie baie konsekwent gebruik nie en word daar in 1873 byvoorbeeld goedkeurend verwys na 'n kandidaat vir 'n parlementsverkiesing se "Liberaal-Conservatieve beginselen". ${ }^{81}$

In 1853, gedurende die vroeë jare van J.J.H. Smuts se redakteurskap, het die blad die term liberaal in 'n positiewe sin gebruik met verwysing na die grondwet wat die Britse regering vir die Kaapkolonie goedgekeur het en spesifiek ook met verwysing na die feit dat 'n gedeelte van die bruin inwoners stemreg sou verkry. ${ }^{82}$ Soos hierbo aangedui, het die koerant tydens die redakteurskap van Hofmeyr die lae eiendomskwalifikasies bevraagteken, veral omdat dit wanpraktyke tydens verkiesings in die hand gewerk het, en oor die moontlikheid om opvoedingskwalifikasies in te stel besin, maar hom nie daarvoor beywer dat stemreg van bruin en swart mense weggeneem word nie. Hofmeyr het hom tydens sy redakteurskap dus by die sogenaamde Kaapse liberale tradisie ten opsigte van stemreg aangesluit. ${ }^{83}$ Meer as twee dekades later, teen die einde van sy politieke loopbaan, was Hofmeyr een van die leidende politici in die Kaapkolonie wat sterk ten gunste daarvan was dat die nie-rassige stemregkwalifikasies van die Kaapkolonie na die totstandkoming van die Unie van Suid-Afrika behoue sou bly wat betref die Kaapprovinsie, soos die kolonie na 1910 bekend sou staan, en daarvoor gesorg het dat hierdie bepaling in die Unie-grondwet net met 'n tweederde meerderheid van albei parlementshuise gewysig sou kon word. ${ }^{84}$

79. Davenport, The Afrikanerbond, 1880-1911, p ix.

80. Vergelyk McCracken, The Cape Parliament, 1854-1910, p 107.

81. De Zuid-Afrikaan, 26 April 1873.

82. De Zuid-Afrikaan, 5 Mei 1853.

83. Vergelyk Davenport, “The Cape Liberal Tradition to 1910", pp 21-34.

84. Hofmeyr en Reitz, Het Leven van Jan Hendrik Hofmeyr (Onze Jan), pp 686-691. In hierdie werk word vermeld dat 'n waaksaamheidskomitee van bruin mense wat hul beywer het vir die behoud van hul stemreg na die stigting van die Unie van SuidAfrika teenoor Hofmeyr, vir sy optrede in hierdie verband, die "onsterfelijke dankbaarheid van alle kleurlingen" betuig het. In antwoord op die dankbetuiging het Hofmeyr in 'n brief aan hulle verduidelik dat maatreëls soos die ontneming van die stemreg van die swart en bruin inwoners van die Kaapkolonie sou indruis teen die handhawing van goeie verhoudinge tussen al die inwoners van die land. Vir die 
Wat betref die beleid wat teenoor die swart mense in die kolonie gevolg moes word, is Hofmeyr se beskouings in ooreenstemming met liberale denke soos wat dit tydens die agtiende-eeuse Verligting in Europa na vore gekom het en wat ook deel van die Kaapse "liberale tradisie" was. ${ }^{85}$ Die opvatting dat die inheemse bewoners barbare is, maar beskaaf en in die Westerse samelewing opgeneem kan word, is reeds in vroeë uitgawes van De Zuid-Afrikaan maar ook tydens Hofmeyr se redakteurskap gehuldig. Hierdie beleid van integrasie was feitlik die teenoorgestelde van die latere apartheidsbeleid.

Volgens die hoofartikels in De Zuid-Afrikaan was Hofmeyr in die jare voor 1884 daarvan oortuig dat grootskaalse immigrasie van veral blankes uit Europa, maar ook van bruin mense uit die Wes-Kaap, na die oostelike dele van die kolonie noodsaaklik was vir die voltrekking van hierdie beskawings- en integrasieproses, sodat die Oos-Kaap, soos reeds in die Wes-Kaap die geval was, 'n gebied met 'n hoofsaaklik Westerse kultuur en samelewing sou word. Soos in die Wes-Kaap moes die blanke bevolking daar die leiding neem. Hofmeyr se bekendheid met die omstandighede in die westelike dele van die kolonie het hom moontlik beïnvloed in sy beskouing van watter soort samelewing wenslik vir die Oos-Kaap sou wees. Dit lyk of hy uit die oog verloor het dat die besondere aard van die Wes-Kaapse samelewing onder meer daardeur bepaal is dat die inheemse bewoners daar, reeds voor die begin van blanke vestiging, veel minder in getal as in die suidoostelike dele van Suid-Afrika was. Verder het die groot kulturele verskeidenheid van die slawe, wat uit verskeie gebiede uit Asië en Afrika ingevoer is, en die feit dat hul van die samelewings waaruit hul afkomstig was afgesny is, daartoe gelei dat hul taamlik vinnig hul oorspronklike kulture verloor en deel van 'n samelewing met 'n sterk Europese inslag geword het.

Waarskynlik het Hofmeyr later besef dat sy visie vir die Oos-Kaap, soos in De Zuid-Afrikaan uiteengesit, nie prakties uitvoerbaar was nie. Hy het hom in die periode na 1883 nie beywer vir grootskaalse vestiging van immigrante uit Europa in hierdie gebied nie, maar op ander wyses gepoog om te verhoed dat swart mense, waarvan die groot meerderheid steeds nie as "beskaaf" of verwesters beskou kon word nie, politieke mag verwerf. Na die inlywing van 'n verdere deel van die gebied oos van die Kei by die Kaapkolonie in $1885,{ }^{86}$ het 'n nog groter getal swart mense in die kolonie gewoon as tevore. Die feit dat die klein gedeelte van die swart mense wat stemreg gehad het, meesal nie vir sy kandidate gestem het nie, het daartoe gelei dat die Afrikanerbond hom sterk vir 'n verandering in stemregkwalifikasies beywer het.

voortbestaan van die blanke bevolking in Suid-Afrika, en in Afrika, is die goedgesindheid van die swart en bruin inwoners van die land van die grootste belang.

85. Vergelyk Trapido, “'The Friends of the Natives', Merchants, Peasants and the Political and Ideological Structure of Liberalism in the Cape, p 267; K. Wilburn, "'Friend of the Native'? James Sivewright and the Cape Liberal Tradition, South African Historical Journal, 65, 2 (2012), p 288.

86. Davenport and Saunders, South Africa: A Modern History, p 147. Van die gebied wat later bekend geword het as die Transkei het slegs Pondoland tot 1894 buite die grense van die kolonie gebly. 
Hofmeyr was steeds nie ten gunste van enige vorm van rassediskriminasie in die stemregstelsel nie, ${ }^{87}$ maar was tog bekommerd daaroor dat die blanke inwoners uiteindelik as ' $n$ minderheid in die kolonie deur die groot swart bevolking oorweldig kon word. Hy het 'n verhoging in die eiendomsvereistes vir die verlening van stemreg voorgestaan en die steun van 'n groot deel van die Engelstalige parlementslede hiervoor gehad. Dit het daartoe gelei dat die Kaapse parlement in 1892 'n wet aanvaar het waarin die eiendomskwalifikasie verhoog en 'n elementêre opvoedingstoets vir die verlening van stemreg ingestel is. ${ }^{88}$ Die besef dat dit nie moontlik sou wees om die inheemse bevolking van Suid-Afrika, in elk geval nie binne die bestek van ongeveer 'n halfeeu, te "beskaaf" of te verwesters nie, wat in die jare na 1880 by Hofmeyr en ander leidende Kaapse politici na vore gekom het, was in ooreenstemming met die verandering in siening van Europese moondhede soos Frankryk, gedurende dieselfde jare, oor wat die oogmerke van hul beleid ten opsigte van hul kolonies in Afrika behoort te wees. ${ }^{89}$

Soos in 'n vorige afdeling hierbo vermeld, was Hofmeyr daarteen gekant dat bruin en swart mense deur uitdruklike bepalings oor lidmaatskapsvereistes verhoed word om lede van die Afrikanerbond te word. Volgens Hofmeyr en Reitz het 'n groepie bruin mense hom by geleentheid gevra of hulle lede van die Bond kon word en het hy hulle geen antwoord gegee nie, maar hulle uitgenooi vir middagete by sy huis. Die bruin mense het toe besef dat hulle so 'n uitnodiging nie kon aanneem nie en om dieselfde rede nie lede van die Afrikanerbond kon word nie; hulle kon nie verwag om in alle opsigte as gelykes van die blankes behandel te word nie. ${ }^{90}$ Uit hierdie anekdote en uit die feit dat geen bruin mense ooit lid van die Afrikanerbond geword het nie, blyk dit dat Hofmeyr veral op sosiale gebied geen gelykstelling van blank en gekleurd voorgestaan het nie. ${ }^{91} \mathrm{Hy}$ het waarskynlik ook, as pragmatiese politikus, besef dat sy blanke ondersteuners sou wou sien dat die kleurskeidslyn op sosiale

87. Davenport, The Afrikaner Bond, 1880-1911, p 122.

88. Giliomee, The Afrikaners, pp 288-290.

89. Frankryk het tot in die laat negentiende eeu 'n beleid van assimilasie in sy kolonies gevolg, wat behels het dat inwoners van die kolonie in die Franse kultuur opgevoed moes word en diegene wat aan bepaalde beskawingsvereistes voldoen het stemreg vir die parlement in Parys sou verkry. In teorie sou die kolonies uiteindelik 'n soortgelyke kultuur en samelewing as Frankryk self hê en sou moederland en kolonies saam 'n groter Frankryk word. Teen die einde van die eeu het verskeie Franse akademici en politici die uitvoerbaarheid van so 'n beleid bevraagteken en in die twintigste eeu is eerder 'n beleid van assosiasie gevolg wat onder meer ingehou het dat inheemse inwoners van die kolonies grotendeels in ooreenstemming met hul eie kulturele agtergrond moes ontwikkel. Vergelyk D.K. Fieldhouse, Colonialism, 1870-1945; An Introduction (Weidenfeld \& Nicolson, London, 1981), pp 37-38.

90. Hofmeyr en Reitz, Het Leven van Jan Hendrik Hofmeyr (Onze Jan), p 342.

91. J. Winch, “J.H. Hofmeyr and the Afrikaner Bond: A Challenge to William Milton's 'Englishness' and the Advance of the 'Coloured' Cricketer", Historia, 59, 1 (2014), pp 18-37, toon aan dat Hofmeyr betrokke was by die organisasie van sport, in besonder krieket, in die Wes-Kaap en dat hy net so min as Rhodes en sy ondersteuners wou sien dat 'n bruin speler by 'n nasionale krieketspan ingesluit word. 
terrein gehandhaaf bly. In hierdie opsig het hy aangesluit by die beskouinge en praktyke van die meeste blanke inwoners van die Kaapkolonie. ${ }^{92}$ De Zuid-Afrikaan het sy lesers gewys op die belangrikheid van goeie verhoudinge tussen blanke Afrikaners en bruin mense, maar veral met die oog daarop dat die bruin mense vir Afrikanerkandidate en die Afrikanerbond stem en om te verhoed dat hulle hulle eerder by die Engelstalige koloniste skaar. Tydens Hofmeyr se redakteurskap het $D e$ Zuid-Afrikaan by geleentheid, in besonder waar dit hulle behandeling in militêre eenhede betref, vir die belange van bruin mense in die bresse getree, maar in die algemeen kan De Zuid-Afrikaan tydens hierdie jare nie as kampvegter vir die bruin en swart mense gesien word nie. Hoewel Hofmeyr in sy politieke beskouinge aansluit by die liberale politieke beginsels wat in hierdie periode deur die meeste politici in die Kaapkolonie aanvaar is wat betref stemreg en opname van bruin en swart mense in die Westerse samelewing, het hy hom nie, soos J.X. Merriman, J.W. Sauer, W.P. Schreiner en andere, in besonder beywer vir die belange van die bruin en swart inwoners van die kolonie nie. Tog het Merriman en Sauer, wat in baie politieke beleidsake rakende die swart mense Onze Jan se teenstanders was, volgens Hofmeyr en Reitz verklaar dat hy "altijd een uiterst matige en uiterst billike man tegenover de naturellen was geweest". ${ }^{93}$

Uit die hoofartikels in De Zuid-Afrikaan kom na vore dat Hofmeyr as koerantredakteur hom veral vir die belange van die Kaapse Afrikaners beywer het en dat sy beskouinge oor vraagstukke rakende bruin en swart mense in die eerste plek bepaal is deur die oorweging van hoe dit die belange van die Afrikaners, en wyer gesien, die blankes en die Westerse beskawing in Suid-Afrika, sou raak. In sy denke oor hierdie vraagstukke het hy hom egter ook steeds deur sy opvattinge oor wat billik en regverdig is laat lei.

92. Giliomee, The Afrikaners, pp 128-129, verwys ook na bogenoemde anekdote en skryf dat Hofmeyr die Afrikaners se tradisionele paternalistiese beskouings ten opsigte van swart en bruin mense probeer versoen het met die liberale idees van vooruitgang, nie-rassige stemreg, gelykheid voor die reg, ensovoorts, wat deur die Afrikanerelite aanvaar is. Daar moet egter hierbenewens in gedagte gehou word dat ook onder Engelstalige koloniste, in die Kaapkolonie en in ander Britse gebiede, negentiendeeeuse liberale politieke idees selde ingehou het dat sosiale skeidslyne tussen blanke koloniste en inheemse bewoners opgehef is. Vergelyk V. Bickford-Smith, Ethnic Pride and Racial Prejudice in Victorian Cape Town (Witwatersrand University Press, Johannesburg, 1995), veral pp 67-90; en S. Marks, “Class, Culture and Consciousness in South Africa, 1880-1899", in Ross, Kelk Mager and Nasson, The Cambridge History of South Africa, Volume 2, 1885-1994, veral pp 118-119.

93. Hofmeyr en Reitz, Het Leven van Jan Hendrik Hofmeyr (Onze Jan), p 341. 


\section{BRONNELYS}

Behr, A.L. and Macmillan, R.G., Education in South Africa, 2nd edition (Van Schaik, Pretoria, 1971).

Bickford-Smith, V., Ethnic Pride and Racial Prejudice in Victorian Cape Town (Witwatersrand University Press, Johannesburg, 1995).

Bosman, F.C.L. en Dreyer, A. Hollandse Joernalistiek in Suid-Afrika gedurende die 19de Eeu en Lewenssketse van Hollandse Joernaliste in Kaapland (uitgewer nie vermeld, Kaapstad, 1930).

Davenport, R., The Afrikaner Bond, 1880-1911 (Oxford University Press, Cape Town, 1966).

Davenport, R., “The Cape Liberal Tradition to 1910", in Butler, J. Elphick, R. and Welsh, D. (eds), Democratic Liberalism in South Africa: Its History and Prospect (David Philip, Cape Town, 1987), pp 21-34.

Davenport, R. and Saunders, C., South Africa: A Modern History (Macmillan, London, 2000).

De Klerk, P., "Afrikanerliberalisme in die Tydperk 1775-1975: Die Interpretasies van G.D. Scholtz en H. Giliomee", The Journal for Transdiciplinary Research in Southern Africa, 7, 2 (2011), pp 139-158.

De Klerk, P., “De Zuid-Afrikaan se Standpunt oor Stemreg vir Bruin Mense voor die Totstandkoming van die Kaapse Koloniale Parlement in 1854", Historia, 59, 1 (2014), pp 1-17.

Du Toit, A., “The Cape Afrikaners' Failed Liberal Moment, 1850-1870”, in Butler, J. Elphick, R. and Welsh, D. (eds), Democratic Liberalism in South Africa: Its History and Prospect (David Philip, Cape Town, 1987), pp 48-63.

Elphick, R. and Giliomee, H., "The Origins and Entrenchment of European Dominance at the Cape, 1652- c. 1840", in Elphick, R. and Giliomee, H. (eds), The Shaping of South African Society, 1652-1840, 2nd edition (Maskew Miller Longman, Cape Town, 1989), pp 521-566.

Evans, J., Grimshaw, P., Philips, D. and Swain, S., Equal Subjects, Unequal Rights: Indigenous Peoples in British Colonies, 1830-1910 (University Press, Manchester, 2003).

Fieldhouse, D.K., Colonialism, 1870-1945: An Introduction (Weidenfeld \& Nicolson, London, 1981).

Giliomee, H., The Afrikaners: Biography of a People, 2nd edition (Tafelberg, Cape Town, 2009).

Hamilton, C., Mbenga, B.K. and Ross, R. (eds), The Cambridge History of South Africa, Volume 1, From Early Times to 1885 (University Press, Cambridge, 2010).

Hofmeyr, J.H. en Reitz, F.W., Het Leven van Jan Hendrik Hofmeyr [Onze Jan] (Van de Sandt de Villiers, Kaapstad, 1913). 
Hofmeyr, J.H. and Reitz, F.W., The Life of Jan Hendrik Hofmeyr [Onze Jan] (Van de Sandt de Villiers, Cape Town, 1913).

Legassick, M., "The Northern Frontier to c. 1840: The Rise and Decline of the Griqua People", in Elphick, R. and Giliomee, H. (eds), The Shaping of South African Society, 1652-1840, 2nd edition (Maskew Miller Longman, Cape Town, 1989), pp 358-420.

McCracken, J.L., The Cape Parliament, 1854-1910 (Clarendon Press, Oxford, 1967).

Marks, S., "Class, Culture and Consciousness in South Africa, 1880-1899”, in Ross, R. Kelk Mager, A. and Nasson, B., The Cambridge History of South Africa, Volume 2, 1885-1994 (University Press, Cambridge, 2012).

Paton, A., Hofmeyr (Oxford University Press, Cape Town, 1971).

Pretorius, F. (red.), Geskiedenis van Suid-Afrika, van Voortye tot Vandag (Tafelberg, Kaapstad, 2012).

Ross, R., Kelk Mager, A. and Nasson, B. (eds), The Cambridge History of South Africa, Volume 2, 1885-1994 (University Press, Cambridge, 2012).

Roux, P.E., “Die Geskiedenis van die Burgerkommando's in die Kaapkolonie, 16521878", D.Phil.-proefskrif, Universiteit van Stellenbosch, 1946.

Scholtz, G.D., Die Ontwikkeling van die Politieke Denke van die Afrikaner, Volume 3, 1854-1881 (Perskor, Johannesburg, 1974).

Trapido, S., "'The Friends of the Natives', Merchants, Peasants and the Political and Ideological Structure of Liberalism in the Cape, 1854-1910", in Marks, S. and Atmore, A. (eds), Economy and Society in Pre-industrial South Africa (Longman, London, 1980), pp 247-274.

Trapido, S., "The Origins of the Cape Franchise Qualifications of 1853", Journal of African History, 5, 1 (1964), pp 37-54.

Van Niekerk, A.P., "Smuts, Jacques (Tjaak) Jean Henri (Hendrik)”, in De Kock W.J. en Krüger, D.W. (reds), Suid-Afrikaanse Biografiese Woordeboek, Volume 2 (Tafelberg, Kaapstad, 1972), pp 697-698.

Wilburn, K., "Friend of the Native'? James Sivewright and the Cape Liberal Tradition", South African Historical Journal, 65, 2 (2012).

Winch, J., “J.H. Hofmeyr and the Afrikaner Bond: A Challenge to William Milton's 'Englishness' and the Advance of the 'Coloured' Cricketer", Historia, 59, 1 (2014). 